\title{
PERANCANGAN PESAN UNTUK MENINGKATKAN INTENSI PERILAKU HEMAT DALAM MENGGUNAKAN AIR
}

\author{
Hasrini Sari, Ratna Dewi Gantini
}

Program Studi Manajemen Rekayasa Industri Insitut Teknologi Bandung; e-mail: hasrinis@gmail.com

\begin{abstract}
ABSTRAK
Ketersediaan potensi air bersih di Indonesia menurun, sehingga kontribusi dari semua pihak diperlukan untuk mengatasi masalah ini. Salah satunya adalah dengan mendorong perilaku hemat air dari penggunanya melalui pemaparan pengetahuan atau pemahaman tentang kondisi ketersediaan air dan kualitas air di masa sekarang dan di masa depan. Upaya mendorong orang untuk menggunakan air secara bijak dapat dilakukan dengan menyampaikan pesan yang dirancang dengan baik. Penelitian ini bertujuan untuk mengidentifikasi karakteristik pesan yang efektif untuk mendorong masyarakat menjadi lebih hemat dalam menggunakan air dengan mengadopsi Hierarchy of Effect Model dan metode anchor. Pesan akan mempengaruhi penerima secara bertahap mulai dari aspek kognitif, afektif dan niat. Sementara anchor digunakan dalam pesan untuk menciptakan keadaan pikiran yang diinginkan untuk meningkatkan efektivitas pesan yang disampaikan. Metode penelitian yang digunakan adalah desain eksperimen. Dalam penelitian pendahuluan, ditemukan bahwa stimulus yang mengandung isi pesan yang memberikan efek takut memiliki tingkat yang signifikan dalam mempengaruhi intensi partisipan. Eksperimen pertama dari penelitian utama membuktikan hubungan hirarkis antara aspek kognitif, afektif dan intensi. Eksperimen kedua dari penelitian tersebut menemukan bahwa jenis konten pesan yang dapat meningkatkan intensi masyarakat untuk menggunakan air dengan bijaksana adalah jenis konten pesan yang menimbulkan efek takut terhadap konsekuensi dari penggunaan air yang berlebihan.
\end{abstract}

Kata kunci: Anchor, desain eksperimen, Hierarchy of Effect Model, pesan, intensi, hemat air

\begin{abstract}
The availability of clean water potential in Indonesia is decreasing, so that contributions from all parties are needed to overcome these problems. One of them is by encouraging water-saving behavior from its users through providing knowledge or understanding of the conditions of water availability and water quality in the present and in the future. Efforts to influence people to use water wisely can be done by conveying messages that are well designed. This study aims to identify effective message characteristics to encourage people to be more efficient in using water by adopting the Hierarchy of Effect Model and anchor method. Messages will affect recipients gradually starting from cognitive, affective and intention aspects. While the anchor is used in the message to create the desired state of mind in order to increase the effectiveness of a message delivered. The research method used was experimental design. In the preliminary study, it was found that a stimulus containing the message content of fear effects had a significant degree in influencing participants' intentions. The first experiment of the main study proves a hierarchical relationship between cognitive, affective and intention aspects. The second experiment of the study found that the type of message content that can increase people's intention to use water wisely was a type of message content that has the effect of fearing the consequences of excessive water usage.
\end{abstract}

Keywords: anchor, experiment design, Hierarchy of Effect Model, message, water-saving behavior

Citation: Sari, H., Gantini, R.D. (2019). Perancangan Pesan untuk Meningkatkan Intensi Hemat dalam Menggunakan Air. Jurnal Ilmu Lingkungan, 17(2), 231-238, doi:10.14710/jil.17.2.231-238

\section{Pendahuluan}

Air merupakan kebutuhan vital bagi kehidupan. Air dibutuhkan untuk memproduksi makanan, kesehatan, proses industri, energi dan lingkungan. Penggunaan air di berbagai sektor sering kali digunakan tanpa mempertimbangkan dampak terhadap sumber daya air dan pengguna air lainnya (Connor \& Stoddard, 2012). Peningkatan populasi yang tajam disertai dengan perkembangan industri yang sangat pesat memberikan pengaruh yang sangat besar terhadap kuantitas dan kualitas air yang mungkin akan menjadi kendala bagi pembangunan berkelanjutan (Kataoka dkk, 2014).

Indonesia memiliki permasalahan kekurangan air bersih di beberapa wilayah. Indonesia sudah mencapai MDG (Millenium Development Goal) dalam hal peningkatan jumlah penduduk yang memiliki akses ke sumber air bersih tahun 2015 yaitu 
sebanyak $68.87 \%$ dari total penduduk Indonesia dan capaian akses air minum di Indonesia mencapai $70,97 \%$ pada tahun 2017. Namun demikian, peningkatan ini diiringi pergeseran sumber pemenuhan kebutuhan air bersih yaitu dari sumber air terlindung menjadi air minum kemasan (BPS, 2017). Hal ini merupakan salah satu indikasi bahwa kualitas air di permukaan tanah semakin menurun sehingga tidak layak lagi untuk dikonsumsi.

Menurut Herlambang (2006 dalam Estika dkk, 2017), besarnya potensi ketersediaan air pada tahun 2020 di Indonesia diperkirakan hanya berkisar 1200 m3/kapita/tahun dan hanya 35\% diantaranya atau sebesar $400 \mathrm{~m} 3 / \mathrm{kapita} /$ tahun yang layak untuk dikelola. Krisis air yang diperkirakan akan terjadi ini bukan disebabkan karena sedikitnya sumber daya air yang tersedia karena pada dasarnya jumlahnya tetap, melainkan disebabkan karena buruknya kondisi lingkungan, kurangnya akses terhadap air bersih, dan tata kelola air yang tidak tepat serta perilaku manusia menjadi tantangan dalam perencanaan dan pengelolaan air (World Water Assesment Programme, 2012). Meskipun penyebab utama dari terjadinya krisis air secara keseluruhan berkaitan dengan fasilitas dan tata kelola air yang berkaitan dengan upaya Pemerintah, ada salah satu penyebab krisis air yang bisa diatasi untuk membantu Pemerintah dalam menanggulangi krisis air, yaitu melalui perubahan perilaku manusia yang tidak peduli terhadap kondisi air bersih dan menggunakan air bersih secara tidak bijaksana.

Salah satu cara yang paling mudah untuk mengurangi dampak negatif dari perilaku manusia tersebut adalah membangkitkan pengetahuan baru atau pemahaman tentang kondisi ketersediaan air dan kualitas air di masa sekarang dan di masa yang akan datang (World Water Assesment Programme, 2012). Masyarakat harus mengerti bahwa air merupakan sumber daya alam yang tergantung pada kegiatan masyarakat, kegiatan ekonomi dan fungsi ekosistem. Effendi (2003) menyatakan bahwa perilaku hemat air perlu ditanamkan pada seluruh penggunanya. Terkait dengan upaya untuk mempengaruhi masyarakat agar menggunakan air secara bijaksana dengan kata lain merubah perilaku dari kurang baik menjadi lebih baik, salah satu caranya adalah dengan menyebarkan informasiinformasi atau pesan yang berkaitan dengan isu krisis air bersih ini kepada khalayak. Contoh kasus nyata pesan sosial yang efektif dalam menciptakan transformasi sosial adalah program penyampaian pesan untuk mengurangi penyakit polio di India. Di tahun 2009 jumlah penderita polio di India terhitung mendekati setengah dari penderita polio di dunia. Dalam kasus ini strategi iklan sosial berkontribusi terhadap perjalanan negara selama 27 tahun hingga akhir, sampai tidak ada satu kasus tercatat sejak tahun 2011 (Lee dan Kotler, 2013; Kumar, 2012). Untuk itu, pesan sosial perlu dirancang dengan baik sehingga dapat mendorong si penerima pesan untuk menampilkan perilaku yang diinginkan.
Proses suatu informasi sebagai stimulus untuk mempengaruhi penerima telah dimodelkan dalam Model Komunikasi Lasswell. Model Komunikasi Lasswell merupakan model komunikasi yang sering diterapkan dalam komunikasi massa. Model komunikasi ini dikembangkan oleh Harold Lasswell pada tahun 1948. Menurut Lasswell persoalan komunikasi terdiri dari lima pertanyaan sederhana yaitu who (siapa/sumber), says what (pesan), in which channel (saluran/media), to whom (siapa/penerima), dan with what effect (dampak/efek) (Mulyana, 2007).

Kemudian informasi yang diterima oleh khalayak baik pesan sosial, maupun iklan komersial akan mempengaruhi khalayak secara bertahap mengikuti teori Hierarchy of Effect Model. Model ini dikembangkan oleh Lavidge dan Steiner pada tahun 1960 (Kotler \& Armstrong, 2008). Pada model tersebut, informasi yang diterima oleh individu akan melalui tiga tahapan, yaitu tahap kognitif, tahap afektif, dan tahap behavioral intention atau intensi. Ketiga aspek ini berpengaruh secara berurutan dalam memproses stimulus yang diterima. Kognitif merupakan variabel dependen yang berkaitan dengan proses berpikir, daya menghubungkan, kemampuan menilai dan kemampuan mempertimbangkan (Chaplin, 1981). Afektif merupakan variabel dependen yang berkaitan dengan sikap dan nilai. Aspek afektif mencakup watak perilaku seperti perasaan (takut, simpati, dengki, dll) minat, sikap, emosi, dan nilai (Krathwohl, 1964). Kemudian yang terakhir yaitu behavioral intention atau intensi merupakan sebuah indikasi seberapa kuat orang berkeinginan untuk mencoba dan seberapa besar usaha yang akan mereka kerahkan untuk menjalankan sikap (Paul \& Jerry, 2005).

Dari sisi psikologi terdapat satu teknik yang digunakan untuk mempengaruhi persepsi seseorang, yaitu teknik anchor atau "jangkar". Konsep "jangkar" dikembangkan oleh Ivan Pavlov pada tahun 1890 (Yuliawan, 2010). Jangkar merupakan suatu stimulus yang digunakan untuk mengakses state of mind (kondisi dari pikiran dan perasaan) tertentu (Sailendra, 2014). Dengan menentukan terlebih dahulu state of mind yang ingin ditimbulkan, maka jangkar yang sesuai untuk menimbulkan state of mind tersebut diterapkan pada informasi yang ingin disampaikan.

Untuk dapat meningkatkan intensi sikap masyarakat agar menggunakan air bersih secara bijaksana, peneliti perlu melakukan penelitian mengenai jenis isi pesan yang efektif terkait dengan hal tersebut. Untuk mengetahui jenis isi pesan seperti apa yang efektif untuk mempengaruhi khalayak agar menggunakan air secara bijak, maka teori-teori yang telah dipaparkan di atas akan diterapkan dan diuji dengan menggunakan desain eksperimen. Desain eksperimen adalah percobaan yang dilakukan untuk mempelajari atau menemukan sesuatu mengenai proses yang ada atau membandingkan efek dari beberapa kondisi terhadap fenomena (Montgomery, 
1991). Dalam praktiknya, desain eksperimen harus memperhatikan faktor-faktor yang harus dikontrol agar efek yang diberikan oleh khalayak merupakan akibat dari perlakuan yang diberikan dalam eksperimen. Dengan demikian peneliti harus mengetahui faktor-faktor yang mempengaruhi persepsi seseorang. Faktor-faktor yang mempengaruhi persepsi seseorang terdiri dari dua jenis yaitu faktor internal dan faktor eksternal (Gibson dkk, 2000). Oleh karena itu, ketika melakukan desain eksperimen, faktor-faktor yang dikontrol adalah faktor internal dan faktor eksternal tersebut. Hasil penelitian ini diharapkan akan dapat dimanfaatkan untuk merancang strategi pesan yang tepat dalam mempengaruhi masyarakat untuk menggunakan air bersih secara hemat sesuai dengan kebutuhan.

\section{Metodologi}

Model yang digunakan dalam penelitian ini adalah integrasi antara Model Komunikasi Lasswell dan Model Effect of Hierarchy. Model penelitian ini dapat dilihat pada Gambar 1. Dari model penelitian pada Gambar 1 dapat dilihat bahwa variabel independen penelitian adalah jenis isi pesan dan variabel dependen penelitian adalah sikap responden dengan kriteria sikap yaitu kognitif, afektif, dan intensi

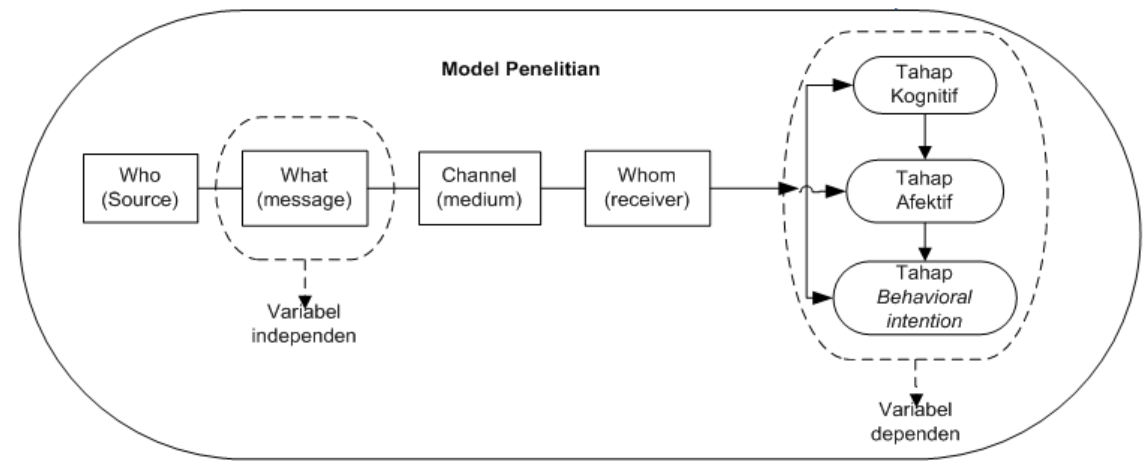

Gambar 1 Model Penelitian

Selain model tersebut, penelitian ini juga menggunakan teknik anchor. Teknik anchor digunakan sebagai satu teknik untuk "menjangkarkan" state of mind (kondisi pikiran dan perasaan) seseorang, sehingga state of mind tersebut bisa distimulus kapan saja dan dimana saja (Sailendra, 2014). Teknik anchor ini digunakan berdasarkan penelitian yang dilakukan oleh Yang dkk (2011) pada penelitian proses kognisi, afeksi dan intensi penerima pesan iklan untuk mencegah perilaku mengemudi dengan kecepatan tinggi. Hasil dari penelitian tersebut menunjukkan bahwa pesan yang menggunakan anchor memiliki pengaruh lebih besar terhadap penerima pesan (kognitif, afektif, dan intensi) dari pada pesan yang tidak menggunakan anchor.

Penelitian ini dilakukan dalam dua tahap, yaitu tahap penelitian pendahuluan dan tahap penelitian utama. Tahap penelitian pendahuluan dilakukan dengan tujuan untuk mengetahui jenis isi pesan yang cocok disampaikan kepada partisipan dan desain penyampaian pesan yang sesuai untuk menarik perhatian partisipan. Hasil dari penelitian pendahuluan digunakan sebagai input untuk penelitian utama. Kemudian tahap penelitian utama merupakan tahap inti dari penelitian untuk menjawab tujuan dari penelitian. Tahap penelitian utama terdiri dari dua eksperimen. Berdasarkan tujuan dari masing-masing penelitian, maka kasus yang diangkat pada studi pendahuluan adalah kasus yang relevan dengan kehidupan mahasiwa sebagai partisipannya yaitu larangan mencontek. Kasus yang dekat dengan kehidupan mahasiswa ini diangkat agar mahasiswa lebih memahami tujuan dari pesan sehingga efek dari setiap jenis pesan dapat lebih akurat dapat dianalisis. Jenis isi pesan yang dirancang dalam studi pendahuluan terdiri dari tiga jenis yaitu jenis isi pesan efek rasa takut, efek sindiran, dan netral. Partisipan dalam penelitian pendahuluan adalah mahasiswa program Sarjana ITB. Sampel diperoleh dengan menggunakan metode stratified random sampling dengan bilangan acaknya adalah nomor induk mahasiswa. Jumlah partisipan untuk setiap jenis isi pesan adalah 37 orang untuk jenis isi pesan efek rasa takut, 39 orang untuk jenis isi pesan efek sindiran, dan 34 orang untuk jenis isi pesan netral.

Pada penelitian utama, kasus yang diangkat adalah terkait dengan ajakan untuk menggunakan air bersih secara bijak. Pada penelitian utama ini, dua eksperimen dilakukan untuk menguji hipotesis penelitian. Perbedaan di antara kedua eksperimen tersebut adalah dalam jenis kelamin, usia dan profesi dari partisipan. Partisipan pada penelitian utama eksperimen satu adalah mahasiswa program sarjana ITB. Sampel yang diambil minimal terdiri dari 30 orang untuk kelompok yang diberikan isi pesan efek rasa takut dan 30 orang untuk kelompok kontrol (isi pesan netral). Sampel pada penelitian utama eksperimen satu dipilih dengan menggunakan metode stratified random sampling.

Sedangkan partisipan pada penelitian utama eksperimen dua adalah para wanita dengan rentang usia 30 tahun ke atas. Target partisipan ini dipilih dikarenakan dua hal, yang pertama para wanita adalah pihak yang paling dipengaruhi di rumah oleh masalah yang berhubungan dengan ketersediaan air. Alasan kedua, berdasarkan hasil penelitian The 
Institute for Women's Policy Research, wanita lebih peduli terhadap lingkungan dibandingkan dengan laki-laki (Sari, 2008; Gifford dan Nillson, 2014).

Sampel ini diambil dengan menggunakan metode convenience sampling, yaitu peneliti mengambil sampel dengan cara meminta para wanita yang ditemui peneliti untuk bersedia mejadi partisipan. Jumlah minimal partisipan untuk masingmasing jenis isi pesan adalah 30 orang.

Jenis isi pesan yang didesain pada penelitian utama terdiri dari dua jenis isi pesan yaitu jenis isi pesan netral sebagai kontrol dan jenis isi pesan yang merupakan output dari studi pendahuluan (salah satu di antara jenis isi pesan efek rasa takut atau efek sindiran).

Metode penelitian yang digunakan adalah desain eksperimen dimana peneliti memberikan stimulus berupa poster yang mengandung isi pesan tertentu kepada para partisipan dan kemudian membandingkan efek dari setiap jenis isi pesan terhadap sikap partisipan dalam hal aspek kognitif, afektif dan intensi. Semua data diolah dengan menggunakan software SPSS V.20. Data pada studi pendahuluan diolah dengan statistika ANOVA karena data terdiri dari tiga jenis kelompok, sedangkan data pada penelitian utama diolah dengan statistika Independent T-Test karena data berasal dari dua kelompok yang berbeda.

Alat ukur yang digunakan dalam penelitian adalah kuesioner. Sebelum memulai proses pengambilan data, terlebih dahulu dilakukan pengujian alat ukur untuk meyakinkan peneliti bahwa alat ukur yang dirancang telah sesuai sehingga tujuan dari penelitian dapat tercapai. Pengujian untuk masing-masing alat ukur dilakukan pada 10 orang sampel dengan pengambilan sampel menggunakan metode convenience sampling.

Selain itu, karena penelitian ini merupakan desain eksperimen sehingga terdapat variabel kontrol yang harus diperhatikan. Variabel kontrol tersebut adalah variabel yang mempengaruhi persepsi seseorang yaitu tekait dengan faktor eksternal dan faktor internal. Faktor eksternal adalah faktor yang mempengaruhi persepsi seseorang yang berkaitan dengan stimulus yang diberikan yaitu desain poster. Aspek yang mempengaruhi persepsi seseorang terkait dengan desain poster menurut Baer (2008) adalah ukuran poster, jenis huruf, dan warna. Aspek eksternal pada penelitian ini dikontrol dengan cara memberikan poster dengan ukuran, jenis huruf dan warna yang relatif sama. Sedangkan faktor internal adalah faktor yang berasal dari dalam diri penerima stimulus. Menurut Gibson dan Donnelly (1996) faktor internal tersebut adalah fisiologis, perhatian, minat, pengalaman dan ingatan, suasana hati, latar belakang, dan usia.

\section{Hasil dan Pembahasan}

Penelitian terdiri dari dua tahap yaitu penelitian pendahuluan dan penelitian utama. Berikut ini adalah hasil dari masing-masing tahap penelitian.

\subsection{Penelitian Pendahuluan}

Pengumpulan data dilakukan dengan memaparkan stimulus pada masing-masing partisipan berupa satu poster yang berisi pesan sosial mengenai mencontek yang memiliki salah satu efek, yaitu menimbulkan rasa takut, sindiran, dan netral. Pesan dengan efek rasa takut dipaparkan pada 36 partisipan; pesan dengan efek sindiran dipaparkan pada 38 partisipan; dan pesan dengan efek netral dipaparkan pada 33 partisipan. Setelah diberi paparan, masing-masing partisipan diminta untuk menjawab beberapa pertanyaan yang mengukur aspek kognitif, afektif dan intensi untuk mencontek.

Setiap orang yang dijadikan partisipan telah memenuhi persyaratan yang harus dipenuhi terkait dengan faktor internal yaitu salah satunya adalah setiap partisipan mampu melihat isi poster dengan jelas. Kemudian setiap partisipan tidak dalam keadaan lelah dan tidak kurang tidur. Hal ini perlu dikontrol untuk menghindari dampak dari kekurangan tidur yaitu antara lain adalah individu menjadi tidak produktif, tidak fokus, pelupa dan pemarah (Indah, 2014). Dari aspek minat, ini telah terpenuhi oleh partisipan terbukti dengan kesediaan untuk berpartisipasi dan menemui peneliti di lokasi yang sudah ditentukan. Selain itu dari segi pengalaman juga sangat penting untuk dipertimbangkan, aspek pengalaman ini berkaitan dengan teori perbandingan sosial yang dikembangkan oleh Leon Festinger (1954). Menurut Festinger, perbandingan penilaian antar dua orang atau lebih akan stabil, akurat dan valid jika proses perbandingan dilakukan antara orang dalam domain yang relevan yaitu yang memiliki kemiripan pendapat (Gernsbacher dkk, 2017). Berdasarkan teori tersebut maka untuk membandingkan pendapat dua orang atau lebih, orang tersebut harus memiliki titik acuan yang sama sehingga perbandingan yang dilakukan menghasilkan evaluasi yang akurat. Dari kontrol pengalaman ini, maka partisipan yang diambil adalah partisipan yang sama-sama pernah mencontek dan/atau dicontek, sehingga pendapat mereka untuk proses penelitian ini dapat dibandingkan karena memiliki titik acuan yang sama berdasarkan pengalaman masa lalu.

Setiap partisipan juga tidak dalam keadaan marah, hal ini perlu dikontrol karena persepsi seseorang terhadap suatu rangsangan yang diterima dalam kondisi normal (netral) akan berbeda dengan kondisi saat emosi tertentu, misalnya marah (Abele dkk, 1998). Variabel kontrol lainnya yang terpenuhi yaitu usia, budaya, latar belakang, dan lokasi.

Setelah data untuk setiap jenis isi pesan yaitu jenis isi pesan efek rasa takut, jenis isi pesan efek sindiran, dan jenis isi pesan netral terkumpul maka dilakukan pengujian dengan uji ANOVA. Uji ANOVA dapat dilakukan jika syarat normal dan homogen telah terpenuhi. Data yang diperoleh berdistribusi normal dan homogen sehingga tahap selanjutnya dapat dilakukan uji ANOVA. Hipotesis yang akan diuji adalah sebagai berikut: 
- $\quad$ H0 = Tidak ada perbedaan rata-rata sikap dari partisipan dengan menggunakan jenis isi pesan yang berbeda.

- $\quad \mathrm{H} 1$ = Ada perbedaan rata-rata sikap dari partisipan dengan menggunakan jenis isi pesan yang berbeda.

Untuk menentukan $\mathrm{H} 0$ atau $\mathrm{H} 1$ yang diterima maka ketentuan yang harus diikuti adalah sebagai berikut:

a. Jika Fhitung > Ftabel maka HO ditolak b. Jika Fhitung < Ftabel maka H0 diterima

Pada uji ANOVA, jika H0 ditolak maka analisis dilanjutkan pada tahap analisis Tukey untuk dilihat poster jenis apa yang lebih berpengaruh, sedangkan jika H0 diterima maka Tukey tidak perlu di analisis lagi karena jika nilai ANOVA tidak signifikan hal ini mengindikasikan bahwa setiap poster pada variabel tersebut tidak memiliki perbedaan pengaruh. Hasil uji ANOVA untuk setiap indikator dapat dilihat pada Tabel 1.

Tabel 1. Hasil Uji ANOVA Penelitian Pendahuluan

\begin{tabular}{|c|c|c|c|}
\hline Variabel & Indikator & $\mathrm{F}$ & Probabilitas \\
\hline \multirow[t]{4}{*}{ Kognitif } & Partisipan mengerti dengan isi pesan & 0,226 & 0,798 \\
\hline & Mencontek perbuatan salah & 1,276 & 0,283 \\
\hline & Mencontek itu merugikan & 0,247 & 0,781 \\
\hline & $\begin{array}{l}\text { Mencontek adalah penyebab kegagalan di } \\
\text { masa yang akan datang }\end{array}$ & 1,975 & 0,144 \\
\hline \multirow[t]{2}{*}{ Afektif } & Sikap malu atau takut untuk mencontek & 3,791 & 0,026 \\
\hline & $\begin{array}{l}\text { Sikap tidak suka dengan perbuatan } \\
\text { mencontek }\end{array}$ & 0,325 & 0,724 \\
\hline \multirow[t]{2}{*}{ Intensi } & $\begin{array}{l}\text { Partisipan berniat akan memberitahukan } \\
\text { kerugian mencontek kepada yang lain }\end{array}$ & 3,968 & 0,022 \\
\hline & $\begin{array}{l}\text { Partisipan berniat akan menghindari } \\
\text { perbuatan mencontek }\end{array}$ & 0,840 & 0,435 \\
\hline
\end{tabular}

Pada Tabel 1 dapat dilihat nilai F hitung untuk masing-masing indikator. Indikator yang memiliki nilai $\mathrm{F}$ hitung lebih besar dari pada $\mathrm{F}$ tabel adalah indikator sikap malu atau takut untuk mencontek (afektif) dan indikator niat akan memberitahukan kerugian mencontek kepada orang lain, sedangkan indikator lainnya memiliki nilai $\mathrm{F}$ hitung lebih kecil dari pada F tabel. Dengan demikian indikator yang memberikan pengaruh berbeda untuk setiap perlakuan adalah sikap malu atau takut untuk mencontek (afektif) dan niat akan memberitahukan kerugian mencontek kepada yang lain (intensi). Oleh karena itu pada kedua indikator tersebut dilakukan analisis lanjutan yaitu analisis Tukey untuk dilihat perlakuan mana yang memiliki pengaruh paling signifikan untuk masing-masing indikator tersebut. Tahapan dalam menganalisis hasil uji Tukey adalah pertama melihat nilai probabilitasnya (sign.), jika nilai probabilitasnya di bawah nilai $\alpha=0.05$ maka berarti perlakuan antara kedua jenis isi pesan yang terkait memiliki perbedaan pengaruh yang signifikan. Setelah itu, untuk mengetahui jenis isi pesan mana yang paling berpengaruh, dapat dilihat dari nilai Mean Difference (I-J). Pada jenis isi pesan yang memiliki perbedaan yang signifikan, maka dilihat nilai Mean Difference (I-J) nya, jika nilainya negatif, berarti jenis isi pesan yang berada di kolom I lebih berpengaruh dibandingkan dengan jenis isi pesan yang berada di kolom J (pembandingnya). Hasil uji Tukey menjelaskan bahwa jenis isi pesan yang berpengaruh secara signifikan untuk memengaruhi aspek afektif dan intensi tersebut adalah jenis isi pesan efek rasa takut.
Implikasi dari hasil penelitian pendahuluan ini adalah sebagai berikut:

1. Isi pesan yang memiliki pengaruh lebih signifikan dalam mempengaruhi aspek afektif dan intensi adalah isi pesan dengan efek rasa takut.

2. Dari hasil studi pendahuluan ini, peneliti mendapat masukan-masukan dari partisipan mengenai desain isi pesan yang sebaiknya dibuat. Desain yang dimaksud dalam hal ini terkait cara penyampaian pesan. Masukanmasukan tersebut yaitu:

a. Alur cerita gambar harus lebih jelas.

b. Pesan yang disampaikan akan lebih baik jika disampaikan dengan cara sedikit tersirat namun tidak menimbulkan makna ganda.

c. Visualisasi dibuat lebih menarik dan mudah dimengerti agar dapat diterima oleh semua orang.

\subsection{Penelitian Utama}

Pada penelitian utama, desain isi pesan yang dibuat adalah isi pesan dengan efek rasa takut yang dibandingkan dengan isi pesan netral. Pada poster dengan isi pesan efek rasa takut, isi pesan ini didesain dengan tujuan untuk menakut-nakuti partisipan melalui kombinasi antara gambar dan kalimat yang menggambarkan akibat dari menggunakan air secara tidak bijak disertai dengan infomasi mengenai jumlah penduduk Indonesia yang masih kekurangan air bersih yang berperan sebagai "jangkar" (Gambar 2a). Sementara isi pesan netral hanya memberikan perintah untuk menggunakan air 
seperlunya (Gambar 2b). Kedua poster didesain oleh orang yang memang ahli di bidang seni.

Kuesioner dalam penelitian utama terdiri dari: (a) 7 pertanyaan yang berkaitan dengan variabel kontrol; (b) 7 pertanyaan yang berkaitan dengan variabel independen dan dependen; dan (c) 1 pertanyaan untuk mengetahui wawasan partisipan mengenai isu kekurangan air bersih di Indonesia. Pertanyaan yang berkaitan dengan variabel kontrol yaitu pertanyaan apakah partisipan cukup tidur atau tidak; pertanyaan apakah partisipan mengalami kejadian yang membuat marah atau tidak dalam perjalanan menuju lokasi pengujian; pertanyaan apakah partisipan dapat melihat isi poster dengan jelas atau tidak; dan pertanyaan-pertanyaan yang berkaitan dengan pengalaman partisipan terkait dengan air bersih. Syarat partisipan adalah orangorang yang pernah melihat orang-orang yang kesulitan memperoleh air bersih, agar semua partisipan memiliki titik acuan yang relatif sama.

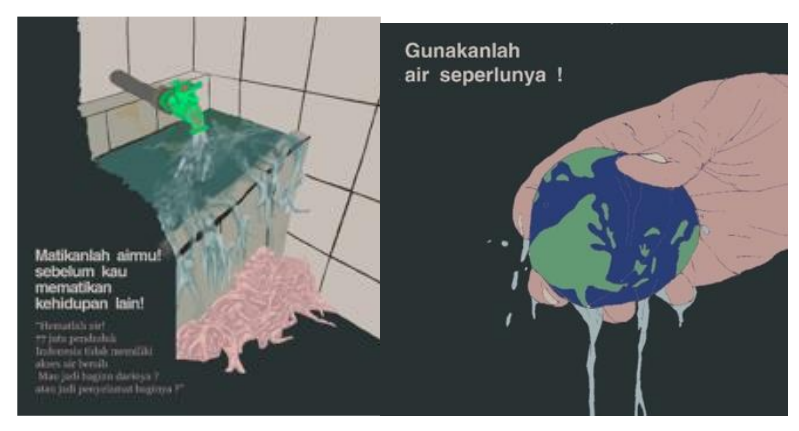

Gambar 2(a) dan (b). Poster Penelitian

\section{Ekperimen 1}

Sampel penelitian diambil dari mahasiswa, dan terdiri dari 45 orang untuk kelompok yang diberikan isi pesan efek rasa takut dan 45 orang untuk kelompok kontrol (isi pesan netral). Metode pengambilan sampel yang dilakukan adalah kombinasi antara stratified random sampling yaitu dengan mengurutkan mahasiswa berdasarkan nomor induk di setiap program studi di ITB lalu memilih partisipan berdasarkan bilangan acak yang dibangkitkan. Ketika pemilik nomor induk yang terpilih tidak bersedia atau berhalangan untuk menjadi partisipan, maka peneliti membangkitkan kembali bilangan acak untuk mengganti partisipan tersebut. Selanjutnya, pengambilan data dilakukan dengan menerapkan prosedur yang sama dengan prosedur pada Studi Pendahuluan.

Data-data yang diperoleh kemudian diolah dan setelah syarat normal terpenuhi, dilanjutkan dengan tahap Independent $T$ Test. Hipotesis yang akan diuji adalah sebagai berikut:

HO = Tidak ada perbedaan rata-rata sikap dari partisipan dengan menggunakan jenis isi pesan yang berbeda.
- $\quad \mathrm{H} 1$ = Ada perbedaan rata-rata sikap dari partisipan dengan menggunakan jenis isi pesan yang berbeda.

Sementara itu, penarikan keputusan berdasarkan perbandingan nilai $t$ hitung dengan $t$ tabel adalah sebagai berikut:

- Jika nilai $t$ hitung positif : nilai $t$ hitung > nilai $t$ tabel maka H0 ditolak

- Jika nilai $t$ hitung negatif : nilai $t$ hitung < nilai $t$ tabel maka $\mathrm{HO}$ ditolak

Confidence level of significant yang digunakan adalah 95\% ( $\alpha=0.05)$. Nilai $t$ tabel 1.99 .

Hasil uji $\mathrm{T}$ dapat dilihat pada Tabel 2 . Berdasarkan hasil Independent T-Test yang dapat dilihat pada tabel tersebut, semua indikator menerima H0 sehingga dapat disimpulkan bahwa tidak ada perbedaan yang berarti antara kedua perlakuan. Kesimpulan tersebut menunjukkan suatu hasil yang di luar dugaan peneliti, karena pada saat studi pendahuluan dengan menggunakan kasus mencontek dengan target yang sama yaitu mahasiswa, terdapat perbedaan sikap antara jenis isi pesan yang berbeda. Selain itu, berdasarkan hasil penelitian yang dilakukan oleh Brennan dan Binney (2010), ada perbedaan sikap pada partisipan dengan menggunakan jenis isi pesan yang berbeda. Oleh karena itu, peneliti menduga bahwa kasus yang diangkat kurang relevan dengan partisipan penelitian.

Namun demikian, pengujian hubungan antara variabel independen dan dependen menunjukkan nilai yang signifikan. Menurut model Effect of Hierarchy, afeksi dipengaruhi oleh kognisi dan intensi dipengaruhi oleh afeksi. Nilai korelasi antara kognitif sebagai variabel independen dan afektif sebagai variabel dependen adalah sebesar 0.532 . Hal tersebut mengindikasikan kekuatan hubungan linier antara dua variabel tergolong kuat. Selain itu, koefisien determinasi (adjusted $R$ square) sebesar 0.275 , yang mengandung pengertian bahwa model yang terbentuk untuk menjelaskan pengaruh variabel bebas (kognitif) terhadap variabel terikat (afektif) adalah sebesar $27.5 \%$, dengan persamaan regresi linier $Y=27.070+0.379 X$; dimana $Y$ merepresentasikan variabel afektif dan $X$ merepresentasikan variabel kognitif.

Sementara nilai korelasi antara afektif sebagai variabel independen dan intensi sebagai variabel dependen adalah sebesar 0.563. Hal tersebut mengindikasikan kekuatan hubungan linier antara dua variabel tergolong kuat. Selain itu, koefisien determinasi (adjusted $R$ square) sebesar 0.309, yang mengandung pengertian bahwa model yang terbentuk untuk menjelaskan pengaruh variabel bebas (afektif) terhadap variabel terikat (intensi) adalah sebesar $30.9 \%$. 
Tabel 2. Hasil Independent T-Test untuk Penelitian Utama

\begin{tabular}{|c|c|c|c|c|c|c|}
\hline \multirow{2}{*}{ Variabel } & \multirow{2}{*}{ Indikator } & \multirow{2}{*}{ Konten Pesan } & \multicolumn{2}{|c|}{ Eksperimen 1} & \multicolumn{2}{|c|}{ Eksperimen 2} \\
\hline & & & $\begin{array}{c}\text { Rata- } \\
\text { rata }\end{array}$ & $\mathrm{t}$ & $\begin{array}{l}\text { Rata- } \\
\text { rata }\end{array}$ & $\mathrm{t}$ \\
\hline \multirow{6}{*}{ Kognitif } & \multirow{2}{*}{$\begin{array}{l}\text { Partisipan mengerti dengan isi pesan yang } \\
\text { disampaikan }\end{array}$} & $\begin{array}{c}\text { Efek rasa } \\
\text { takut }\end{array}$ & 39,27 & \multirow[t]{2}{*}{1,043} & 42,77 & \multirow[t]{2}{*}{0,565} \\
\hline & & Efek netral & 36,73 & & 41,47 & \\
\hline & \multirow{2}{*}{$\begin{array}{l}\text { Partisipan merasa bahwa kebiasaan } \\
\text { menghambur-hamburkan air bersih adalah } \\
\text { salah satu faktor penyebab kekurangan air } \\
\text { bersih di masa yang akan datang }\end{array}$} & $\begin{array}{c}\text { Efek rasa } \\
\text { takut }\end{array}$ & 33,13 & \multirow{2}{*}{24823} & 45,6 & \multirow{2}{*}{4,688} \\
\hline & & Efek netral & 33,07 & & 32,83 & \\
\hline & \multirow{2}{*}{$\begin{array}{l}\text { Partisipan merasa bahwa jika menggunakan air } \\
\text { bersih secara bijak sangat penting di kehidupan } \\
\text { yang akan datang }\end{array}$} & $\begin{array}{l}\text { Efek rasa } \\
\text { takut }\end{array}$ & 39,62 & \multirow[t]{2}{*}{9053} & 46,4 & \multirow[t]{2}{*}{4,427} \\
\hline & & Efek netral & 41,44 & & 39,9 & \\
\hline \multirow{4}{*}{ Afektif } & \multirow{2}{*}{$\begin{array}{l}\text { Partisipan takut dengan dampak dari } \\
\text { menghambur-hamburkan air bersih secara } \\
\text { percuma }\end{array}$} & $\begin{array}{c}\text { Efek rasa } \\
\text { takut }\end{array}$ & 33,71 & \multirow[t]{2}{*}{554} & 45,1 & \multirow[t]{2}{*}{4,897} \\
\hline & & Efek netral & 33,91 & & 37,8 & \\
\hline & \multirow{2}{*}{$\begin{array}{l}\text { Partisipan tidak menyukai sikap menghambur- } \\
\text { hamburkan air bersih }\end{array}$} & $\begin{array}{c}\text { Efek rasa } \\
\text { takut }\end{array}$ & 36,31 & \multirow{2}{*}{1333} & 45,53 & \multirow{2}{*}{4,817} \\
\hline & & Efek netral & 35,42 & & 38,6 & \\
\hline \multirow{4}{*}{ Intensi } & \multirow{2}{*}{$\begin{array}{l}\text { Partisipan akan memberitahukan kerugian } \\
\text { menghambur-hamburkan air bersih kepada } \\
\text { orang terdekat }\end{array}$} & $\begin{array}{c}\text { Efek rasa } \\
\text { takut }\end{array}$ & 30,13 & \multirow[t]{2}{*}{33,5} & 44,37 & \multirow[t]{2}{*}{0,935} \\
\hline & & Efek netral & 27,24 & & 42,57 & \\
\hline & \multirow{2}{*}{$\begin{array}{l}\text { Partisipan akan menggunakan air bersih secara } \\
\text { bijak }\end{array}$} & $\begin{array}{c}\text { Efek rasa } \\
\text { takut }\end{array}$ & 37,93 & \multirow[t]{2}{*}{0,41} & 49 & \multirow[t]{2}{*}{4,097} \\
\hline & & Efek netral & 37,09 & & 44,23 & \\
\hline
\end{tabular}

Sumber data diolah dari hasil uji statistik

Persamaan regresi yang terbentuk adalah $Z$ $=26.449+0.572 Y$; dimana $Y$ merepresentasikan variabel afektif dan $Z$ merepresentasikan variabel intensi. Hubungan antara pengetahuan (kognisi) dan sikap (afeksi) juga ditemukan oleh Azhar dkk (2015).

\section{Ekperimen 2}

Prosedur penelitian pada eksperimen 2 sama dengan eksperimen 1 namun target partisipan adalah wanita usia 30 tahun ke atas. Jumlah partisipan pada eksperimen 2 ini adalah 30 orang. Data-data yang diperoleh pada eksperimen 2 setelah diuji ternyata memenuhi syarat normalitas, maka selanjutnya diolah dengan Independent T-Test. Hipotesis yang akan diuji sama dengan hipotesis pada eksperimen 1 . Hasil uji T dapat dilihat pada Tabel 2.

Berdasarkan hasil Independent T-Test pada Tabel 2, dapat disimpulkan bahwa isi pesan efek rasa takut memiliki pengaruh lebih besar dalam mempengaruhi dua indikator dari aspek kognitif, semua indikator afektif dan satu indikator intensi masyarakat untuk menggunakan air secara bijak. Tahap selanjutnya yaitu perwujudan sikap ke dalam bentuk perilaku hemat air dibuktikan dengan adanya korelasi yang signifikan antara sikap dengan perilaku ramah lingkungan (Azhar dkk, 2015).

Penggunaan efek rasa takut pada penyampaian pesan sudah dilakukan banyak dilakukan. Di bidang kesehatan, penelitian terhadap pesan rasa takut dilakukan oleh Shi dan Smith (2015). Hasil penelitian tersebut menunjukkan bahwa pesan tersebut efektif dalam mempengaruhi sikap dan intensi partisipan ke arah yang diinginkan. Paek dkk (2016) menemukan bahwa pesan yang membangkitkan rasa takut dapat meningkatkan persepsi terhadap resiko penyakit dan intensi untuk membicarakannya.

Di bidang pemasaran sosial, rasa takut sudah secara luas digunakan dalam penyampaian pesan (Hastings dkk, 2004). Penelitian-penelitian pun sudah banyak yang membuktikan efektivitas pesan dengan rasa takut untuk membangkitkan sikap tertentu.

Oleh karena itu, pesan yang membangkitkan rasa takut dapat digunakan dalam mendorong perilaku hemat air. Namun demikian, penggunaan lebih lanjut dari pesan tersebut perlu mempertimbangkan aspekaspek lain. Salah satunya adalah pesan yang menimbulkan rasa takut dapat memicu dampak lain yang tidak diinginkan. Contoh dampak tersebut adalah timbulnya kecemasan yang berlebihan pada individu tertentu, dan peningkatan kesenjangan sosial antara kelompok individu yang merespon pesan tersebut dan kelompok yang tidak merespon (Hastings dkk, 2004).

Aspek berikutnya adalah memastikan respon yang diberikan oleh penerima pesan sudah sesuai dengan tujuan penyampaian pesan. Brennan dan Binney (2010) menemukan bahwa iklan yang mengandung pesan untuk membangkitkan rasa takut lebih mudah diingat dengan akurat oleh partisipan. Respon yang ditimbulkan oleh pesan tersebut cenderung ke arah perlindungan diri sendiri atau 
keluarga. Jadi, penelitian lebih lanjut perlu dilakukan untuk memastikan bentuk perilaku yang ditampilkan setelah menerima pesan tersebut.

\section{Kesimpulan}

1. Isi pesan efek rasa takut memiliki pengaruh lebih besar dalam mempengaruhi aspek afektif dan intensi dibandingkan isi pesan efek sindiran atau isi pesan netral.

2. Karakteristik jenis isi pesan yang sesuai untuk meningkatkan intensi sikap masyarakat agar menggunakan air secara bijak adalah sebagai berikut:

- Jenis isi pesan yang dapat meningkatkan aspek kognitif, afektif dan intensi masyarakat agar menggunakan air secara bijak adalah jenis isi pesan yang dapat memberikan efek rasa takut pada masyarakat terhadap akibat dari penggunaan air secara berlebihan.

- Adanya penggunaan jangkar. Penetapan jangkar yang digunakan menjadi faktor penting yang harus dipertimbangkan dalam mendesain isi pesan. Jangkar ini sangat efektif untuk menimbulkan state of mind yang diinginkan pada diri partisipan sehingga partisipan terpengaruh untuk berperilaku sesuai dengan yang diinginkan. Jangkar yang efektif untuk menimbulkan state of mind rasa takut untuk mempengaruhi masyarakat agar menggunakan air bersih secara bijak adalah kombinasi antara gambar air yang keluar dari keran kamar mandi berupa orang dan banyaknya penduduk yang kekurangan air bersih.

\section{DAFTAR PUSTAKA}

Abele, A., G.H.E. Gendolla., dan P. Petzold. 1998. Positive Mood and In-Group--Out-Group Differentiation in a Minimal Group Setting, Personality \& Social Psychology Bulletin. 24(12), hal. 1343.

Azhar, M., M.D..Basyir, dan Alfitri. 2015. Hubungan Pengetahuan dan Etika Lingkungan dengan Sikap dan Perilaku Menjaga Kelestarian Lingkungan, Jurnal Ilmu Lingkungan, Vol. 3 (1), hal. 36-41.

Baer, K. 2008. Information Design Workbook. RockPort Publisher.

Bappenas. 2017. Kejar Target 100 Persen Akses Air Minum dan Sanitasi di 2019, Bappenas Optimalkan DAK dan Dana Desa. https://www.bappenas.go.id/id/beritadan-siaran-pers/kejar-target-100-persen-akses-airminum-dan-sanitasi-layak-di-2019-bappenasoptimalkan-dak-dan-dana-desa/

Brennan, L., dan W. Binney. 2010. Fear, Guilt, and Shame Appeals in Social Marketing, Vol. 63 (2): 140-146. Journal of Bussiness Research.

Chaplin, J. 1981. Kamus Lengkap Psikologi. Terj. Kartini Kartono. Jakarta: PT Raja Grafindo Persada.

Connor, R., dan H. Stoddard. 2012. Managing Water under Uncertainty and Risk: Recognizing teh Centrality of Water and Its Global Dimensions. UNESCO.

Effendi, H. 2003. Telaah Kualitas Air: Bagi Pengelolaan Sumber Daya dan Lingkungan Perairan. Kanisius, Yogyakarta
Gernsbacher, M.A, J.L. Stevenson., dan S. Dern. 2017. Specificity, contexts, and reference groups matter when assessing autistic traits. PLoS One; San Francisco, 12(2).

Gibson, J. L., J. M. Ivancevich, dan J. Donnelly. H. 2000. Organization: Behaviour, Structure and Process. Boston: McGraw-Hill Companies Inc.

Gifford, R. dan A. Nilsson. 2014. Personal and social factors that influence pro-environmental concern and behaviour: A review. International Journal of Psychology, Vol. 49(3), hal. 141-157.

Hastings, G., M. Stead dan J. Webb. 2004. Fear appeals in social marketing: Strategic and ethical reasons for concern. Psychology \& Marketing, 21(11): 961-986.

Indah, Y. 2014. Makalah Seminar Psikologi Klinis: Insomnia pada Lansia. Jakarta: Universitas Islam Indonesia.

Kataoka, Y., T. Kuyama, dan P. Bao Ngoc. 2014. Water Environment Partnership in Asia (WEPA) Second Phase Final Report. Japan: Ministry of the Environment.

Kotler, P., dan G. Armstrong. 2008. Principles Of Marketing, International Edition. Jilid 12. London: Prentice Hall.

Krathwohl, D. 1964. Taxonomy of Educational Objectives: Handbook II, Affective Domain. New York: David McKay.

Kumar, S. 2012, Juli 18. The Journey to a Polio Free India. UNICEF.

Lee, N. R., dan P. Kotler. 2013. Social Marketing: Changing Behaviors for Good 5th edition. New York: SAGE Publications.

Montgomery, D. C. 1991. Design and Analysis of Experiments. New York: John Wiley \& Sons.

Mulyana, D. 2007. Ilmu Komunikasi. Bandung: PT Remaja Rosdakarya.

Paek, H., S. Oh dan T. Hove. 2016. How Fear-Arousing News Messages Affect Risk Perceptions and Intention to Talk About Risk. Health Communication, 31(9): 10511062.

Paul, J.P., dan C.O. Jerry. 2005. Consumer Behaviour, Perilaku Konsumen dan Strategi Pemasaran Edisi 4. Jakarta: Erlangga.

Sailendra, A. 2014. Neourro-Linguistic Programming (NLP): Dari Konsep Hingga Teknik. Yogyakarta: Bhafana Publishing.

Sari, H. 2008. Peran Pesan Edukasi Pelanggan, Peduli Lingkungan dan Sikap Membeli terhadap Intensi Membeli Produk Hijau, Disertasi, Universitas Indonesia.

Shi, J. dan S.W. Smith (2015). The effects of fear appeal message repetition on perceived threat, perceived efficacy, and behavioral intention in the extended parallel process model. Health Communication, 31(3): 275-286.

UNICEF Pusat Media. 2014, Maret 21. Hari Air Sedunia 2014 Akses terhadap air bersih di Indonesia masih tertinggal. UNICEF Indonesia.

Wira Study Team. 2012. Indonesia Water Investment Roadmap 2011-2014. The World Bank.

WWAP (World Water Assesment Programme). 2012. The United Nations World Water Development Report 4: Managing Water under Uncertainty and Risk. Paris: UNESCO.

Yang Jen, D., J. Lo Yu, dan W. Lin Chen. 2011. Psychological Reports: The Effect of Social Marketing Communication on Safe Driving Vol. 109 (3): 739754. Psycological Reports. 
Yuliawan, P. T. 2010. Neuro-Linguistic Programming: The Art Of Enjoying Life. Jakarta: PT Gramedia Utama
Pustaka. 